\title{
Prince Saprai* \\ The convergence of contract law in Europe and the problem of legitimacy: a common lawyer's perspective
}

DOI 10.1515/ercl-2016-0007

\begin{abstract}
In 2001, the European Commission mooted the idea that contract law should converge in Europe. The idea generated wide-ranging debate about the merits of convergence. The multi-disciplinary nature of this debate has led to important insights, but also conceptual confusion. In this paper, I rely on philosophical tools to clarify key concepts, and identify central issues. In particular, I argue that value pluralism and state sovereignty give rise to the central problem of the legitimacy of the harmonisation project. The issue of legitimacy has not been handled well in the literature. There has been an overly narrow focus on the issue of constitutional legitimacy, or the notion of 'legitimacy as consent'. I attempt to broaden the discussion by considering other accounts of legitimacy. I argue that whichever account is used, the legitimation burden is significant and it is unclear it has been surmounted. Beyond legitimacy, I consider how efficacy considerations seem to militate against convergence.
\end{abstract}

Résumé: En 2001, la Commission européenne a avancé l'idée que le droit des cotnrats devrait converger en Europe. L'idée a engendré un débat très étendu sur les mérites de la convergence. La nature multi-disciplinaire de ce débat a donné lieu à des analyses éclairantes mais aussi à une certaine confusion conceptuelle. Cet article utiise des outils philosophiques pour clarifier des concepts -clé et identifier des questions centrales. En particulier, le pluralisme des valeurs et la souveraineté étatique apparaissent comme étant le problème central en termes de légitimité du projet d'unification. La question de la légititmié n'a pas été bien traité en doctrine. Celle-ci a porté de façon trop étroite sur la légitimité constitutionnelle, ou sur la légitimité réduite au consentement. Il s’agit donc d'élargir la discussion en considérant d'autres formes de légitimité. Or, quelle que soit la conception qui est retenue de cette dernière, la charge de persuasion est lourde et ne semble pas avoir été remplie. Au delà de la légitimité, des considérations d'efficieice semblent militer contre la convergence.

${ }^{*}$ Corresponding author: Prince Saprai, Senior Lecturer, University College London, E-Mail: p.saprai@ucl.ac.uk 
Kurzfassung: 2001 verkündete die Europäische Kommission einen Strategiewechsel: seitdem ging die Strategie nicht mehr primär dahin, Vertragsrecht in der EU konvergieren zu lassen. Dies löste eine breite Diskussion zur Frage nach den Vorund Nachteilen von Konvergenz aus. Der multidisziplinäre Zuschnitt dieser Debatte hat zu wichtigen neuen Erkenntnissen geführt, jedoch auch zu einer Konfusion bei den Konzepten. In diesem Beitrag werden philosophische Instrumente herangezogen, um Kernkonzepte zu klären und Zentralfragen herauszukristallisieren. Vor allem wird dahingehend argumentiert, dass Wertepluralismus und Staatensouveränität das Kernproblem auf den Plan rufen, wie und wie weitgehend denn Harmonisierung überhaupt zu rechtfertigen ist. Diese Legitimitätsfrage wurde im Schrifttum nicht adäquat erörtert. Sie wurde zu sehr auf verfassungsmäßige Legitimität eingeengt, mit einem Konzept einer "Legitimität durch Konsens“. There has been an overly narrow focus on the issue of constitutional legitimacy, or the notion of 'legitimacy as consent'. In diesem Beitrag sollen andere Formen von Legitimität erörtert und so der Fokus erweitert werden. Das Hauptargument geht dahin, dass bei all diesen Formen die Darlegungslast erheblich ist und dass es sehr zweifelhaft ist, ob man ihr hinreichend gerecht wurde. Jenseits von Fragen der Legitimität, werden auch Effizienzüberlegungen angeführt, die ebenfalls gegen (mehr) Konvergenz zu sprechen scheinen.

Keywords: European contract law, contract law, harmonisation, legitimacy, value pluralism, state sovereignty, legitimacy

\section{Introduction}

The comparative lawyer has taught us that the contract law of the Member States of the European Union (EU) diverges in significant respects. By divergence, I mean that even though the relevant facts of cases to be decided may be roughly the same between jurisdictions, the rules, principles and doctrines that are relied on by the courts to decide cases differ in important respects. I don't mean that the outcome, who wins and who loses, necessarily differs between jurisdictions. It may be that the outcomes are the same. Yet, there may still be divergence. The outcomes may be the same but the applicable rules and doctrines may nevertheless differ, and those differences may manifest themselves by affecting outcomes in future cases. ${ }^{1}$

1 I don't adopt the prevailing 'functional' approach to comparative law. See K. Zweigert and H. Kötz, An Introduction to Comparative Law (translated by Tony Weir, $3^{\text {rd }}$ ed, Oxford: Oxford 
Comparisons between English and French law provide a treasure trove of examples. In English law a contract is only enforceable if there is an exchange, or something of value, 'consideration', is given by the promisee in return for the promise. In contrast, French law recognises the gratuitous promise as a category of contract (contrats à titre gratuit). In France, the absence of a bargain does not prevent a contract from coming into existence. ${ }^{2}$

In England, the availability of damages on a cost of cure basis, ie, the cost of obtaining the bargained for performance from a third party, is in certain contexts severely curtailed by a reasonableness requirement. So, for example, in Ruxley Electronics \& Construction Ltd v Forsyth, the promisee could not claim damages on a cost of cure basis when his swimming pool was built shallower than the contractually specified depth. The House of Lords judged that the depth of the pool did not affect its use, and for that reason it would be unreasonable and disproportionate to award cost of cure damages, which would have amounted to more than $£ 21,000 .^{3}$ In contrast, in French law, awards of cost of cure damages are not similarly curtailed. In a recent monograph comparing English and French approaches to remedies for breach of contract, Soléne Rowan cites examples of French cases, which suggest strongly that had Ruxley been decided in France cost of cure would have been awarded. ${ }^{4}$ So, for example, cost of cure was awarded by the Cour de cassation when a house was built a metre or so lower than the height specified in the contract. This breach did not affect the use of the house, but nevertheless cost of cure was deemed the appropriate measure of damages. ${ }^{5}$

There are many other examples of divergence between English and French contract law, relating for example to the interpretation of contracts and mistake, ${ }^{6}$

University Press, 1998) 34. According to which, the test for divergence is whether when the facts of cases are the same between jurisdictions, the outcomes differ or are the same. When they are the same, there is convergence, because although the applicable rules or doctrines may differ they achieve the same result or perform the same function. I believe such approaches are liable to mislead. This is because the outcome may be the same in particular cases, but be based on divergent rules and doctrines which may lead to different results in future cases. These approaches fail to take these rules and doctrines seriously.

2 Arts 1105-1106 Code Civil; A. de Moor, 'Contract and Agreement in English and French Law' (1986) 6 Oxford Journal of Legal Studies 275, 281-282.

3 [1996] AC 344.

4 S. Rowan, Remedies for Breach of Contract: A Comparative Analysis of the Protection of Performance (Oxford: Oxford University Press, 2012) 117-118.

5 Cass Civ 3e, 5 December 1979, JCP 1981, II, 19605. Cited by Rowan, n 4 above, ibid 118.

6 C. Valcke, 'On Comparing French and English Contract Law: Insights from Social Contract Theory' (2009) 4 Journal of Comparative Law 69; A. de Moor, 'Are Contracts Promises?', in J. Eekelaar and J. Bell (eds), Oxford Essays in Jurisprudence: Third Series (Oxford: Clarendon Press, 1997) 103, 117. 
the availability of damages for non-pecuniary loss, ${ }^{7}$ the enforceability of penalty clauses, ${ }^{8}$ the availability of specific performance, ${ }^{9}$ and whether the promisee is required to mitigate his loss. ${ }^{10}$

For over a decade now, there has been a serious debate in both academic and policy circles about whether and how to eliminate these kinds of differences in the contract law of Member States of the European Union. It was triggered by the European Commission's consultation document Communication on European Contract Law, ${ }^{11}$ and has now led to the development of a Draft Common Frame of Reference (DCFR), which aimed to establish a common set of contract law rules and principles for Europe. ${ }^{12}$

The DCFR had a threefold purpose. First, improve the coherence of European contract law legislation, known as the acquis. Second, guide Member States in the development of their own contract law. And third, serve as the foundation for a non-sector specific 'Optional Instrument'. ${ }^{13}$ Until recently, it looked like this Optional Instrument would implement a Common European Sales Law (CESL), which contracting parties could opt into using a choice of law clause. ${ }^{14}$ However, the proposal has now been withdrawn. ${ }^{15}$ Replacing it are proposals for two Directives, one covering the supply of digital content, and the other the online sale of goods. Together, they will according to the Commission '... fully harmonise

7 Rowan, n 4 above, 121-128: 'Whilst compensation for non-pecuniary loss is heavily circumscribed in England, it is widely available in France' (121).

8 L. Miller, 'Penalty Clauses in England and France: A Comparative Study' (2004) 53 International and Comparative Law Quarterly 79; Rowan, $\mathrm{n} 4$ above, 184-188, 197-198.

9 L. Miller, 'Specific Performance in the Common and Civil Law: Some Lessons for Harmonisation', in P. Giliker (ed), Re-examining Contract and Unjust Enrichment: Anglo-Canadian Perspectives (Leiden: Brill, 2007) 281, 287-288: 'in the common law the primary remedy for breach is damages, and specific performance is awarded only very exceptionally. In contrast, in civilian jurisdictions, specific performance receives a far more favourable reception and, where the victim of the breach opts to pursue this remedy, the court will rarely choose to substitute it with damages'. See also Rowan, $\mathrm{n} 4$ above, 17-55.

10 Rowan, $n 4$ above, 142-155: 'English law restricts damages through the [mitigation] principle, requiring the injured promisee to take reasonable steps to avoid loss... In contrast, there is presently no place for loss mitigation in French law' (154-155).

11 Commission, 'Communication from the Commission to the Council and the European Parliament on European Contract Law' COM(2001) 398 final. See also the Commission's response to the consultation, 'A More Coherent European Contract Law, an Action Plan' COM(2003) 68 final.

12 C. von Bar and E. Clive (eds), Principles, Definitions and Model Rules of European Private LawDraft Common Frame of Reference (DCFR), vol 1 (Oxford: Oxford University Press, 2010).

$13 \operatorname{COM}(2003) 68$ final, $n 11$ above, para 62.

14 Commission, 'Proposal for a Regulation on a Common European Sales Law' COM(2011) 635 final.

15 Commission, ‘Work Programme 2015: A New Start’ COM(2014) 910 final, Annex 2, 12. 
in a targeted way the key mandatory rights and obligations of the parties to a contract for the supply of digital content and the online sales of goods'. ${ }^{16}$ These new proposals form part of the Commission's Digital Market Strategy. ${ }^{17}$

The European Commission hoped by means of the DCFR to bring about the greater convergence of contract law in Europe. The focus was on the general law of contract, and not as in the past specific areas of contract, such as consumer law. ${ }^{18}$ This alone makes these developments hugely significant, regardless of how convergence is ultimately brought about, ie, through the use of an optional or binding instrument. ${ }^{19}$ The justification given was economic: divergence was seen as a significant barrier to cross-border trade within the EU, and hence an obstacle to the creation of an internal market.

The Commission's consultation paper and the creation of the DCFR have led to wide-ranging debates about whether contract law should converge in Europe. They have involved multiple disciplines, and although this has led to important insights, it has also generated considerable conceptual confusion. Take, for example, the notion of 'national legal culture', the preservation of which has been used as an argument against convergence. As Martijn Hesselink explains, it is unclear from the literature exactly what it means:

The concept of legal culture and its ingredients (language, values, style, concepts, institutions, consumer preferences etc) are understood in many different ways by different authors and the arguments also differ a great deal in sophistication and intensity. Sometimes they are inspired by postmodernism, sometimes by cultural anthropology, sometimes by political science, often by a combination of these. ${ }^{20}$

The confusion that this lack of precision is apt to create is obvious. In this paper, I am going to rely on some philosophical tools to clarify some of the key concepts and issues that feature, or indeed should feature, in these debates.

I won't offer a detailed commentary on this process of harmonisation, or its likely chances of success. ${ }^{21}$ Nor am I going to discuss the particular ways in which

16 Commission, 'Digital Contracts for Europe - Unleashing the Potential for E-commerce' COM (2015) 633 final, 3.

17 Commission, 'A Digital Market Strategy for Europe' COM(2015) 192 final, 4-5.

18 M.W. Hesselink, 'European Contract Law: A Matter of Consumer Protection, Citizenship, or Justice?' (2007) 15 European Review of Private Law 323, 344.

19 R. Sefton-Green, 'Sense and Sensibilities: The DCFR and the Preservation of Cultural and Linguistic Plurality' (2008) 4 European Review of Contract Law 281, 289.

20 M.W. Hesselink, 'The Case for a Common European Sales Law in an Age of Rising Nationalism' (2012) 8 European Review of Contract Law 342, 346.

21 For an excellent account see L. Miller, The Emergence of EU Contract Law: Exploring Europeanization (Oxford: Oxford University Press, 2011). For a longer-term view see R. Zimmermann, 
the DCFR might be used to promote harmonisation. There are a number already on the table, from its use as the basis for an optional instrument for cross-border transactions, or as a 'toolbox' or set of non-binding guidelines for European legislators, or most radically as the foundation of a European Civil Code. ${ }^{22}$

The issue of how convergence is brought about is of course extremely important, and bears on whether convergence should happen. However, I'm going to try and focus, in this paper anyway, just on the latter should question without getting too involved with the how question. I do this for purely pragmatic reasons. My aim here is just to clarify concepts, bring out key issues and indicate some of the normative hurdles that the harmonisation project faces. These matters are important and have to be addressed, I believe, no matter how harmonisation is actually implemented (although I acknowledge that certain ways of harmonising, for example, through the creation of a European Civil Code, face them far more acutely than others). ${ }^{23}$

I will make three claims. First, the central problem that a harmonisation project of this kind faces is the problem of legitimacy. The problem arises because of the existence of value pluralism, and the value of state sovereignty. Second, the problem of legitimacy goes beyond the issue of state consent, ie, whether treaty provisions provide for harmonisation in this sphere. Rather, other theories of the conditions of legitimacy have to be considered. Whichever theory is adopted, the legitimation burden is significant. It is not the primary purpose of my article to assess whether convergence in this context is legitimate. However, I will raise some doubts in the course of the discussion about whether the relevant condi-

'Roman Law and the Harmonisation of Private Law in Europe', in A.S. Hartkamp, M.W. Hesselink, E.H. Hondius, C. Mak and C.E. du Perron (eds), Towards a European Civil Code $\left(4^{\text {th }}\right.$ ed, The Hague: Kluwer Law International, 2004) 21.

22 According to Stefan Vogenauer the latter option was clearly what the drafters of the DCFR intended. See European Union Committee, 'European Contract Law: the Draft Common Frame of Reference $12^{\text {th }}$ Report' [Session 2008-09] HL Paper (2008-2009) no 95, 12, para 21. However, politically speaking, it is the least likely outcome. See 26, para 83.

23 See H. Beale, 'The Future of the Common Frame of Reference' (2007) 3 European Review of Contract Law 257, 267-268. The issue I want to bracket here is one of the precise normative implications of these more general concerns. See D. Kennedy, 'Thoughts on Coherence, Social Values and National Tradition in Private Law', in M.W. Hesselink (ed), The Politics of a European Civil Code (The Hague: Kluwer Law International, 2006) 9, 24, claiming that the notion of legal culture or tradition 'might be an argument for limiting the area to be harmonised to avoid areas where conflict in national rules is either great or of great symbolic importance. It might be an argument for harmonising slowly rather than rapidly. And it might be an argument for harmonising by 'soft law' rather than 'hard law'. It might also be an argument for harmonising not by regulatory soft law but by 'dialogue' between jurists, professors, judges and others, of different systems'. 
tions of legitimacy have been satisfied. Finally, I will argue that legitimacy is not the only relevant normative consideration in this context. I will illustrate this by considering the issue of efficacy and the practical obstacles to convergence that it raises.

\section{Pluralism and state sovereignty}

Anxiety about state sovereignty is often expressed in the convergence literature. ${ }^{24}$ However, what motivates this worry is rarely unpacked. The underlying issue is state freedom. The value of state sovereignty in this context resides in the freedom of states to decide how they interpret and balance the values that shape contract law. ${ }^{25}$ This matters because the contract law rules and doctrines chosen by Member States play an important role in constituting and expressing national character or identity. ${ }^{26}$ As the Study Group on Social Justice in European Private Law says: 'any system of contract law expresses a set of values, which strives to be coherent, and which is regarded as fundamental to the political morality of each country'. ${ }^{27}$ Against this backdrop, the EU's harmonisation programme 'may be regarded as a disproportionate and illegitimate interference with the diversity of national and local political and legal traditions' ${ }^{28}$

The expressive potential of state sovereignty depends on the existence of an irreducible plurality of ways in which the values that shape contract law might be interpreted, which I will call 'interpretive pluralism', and an irreducible plurality of ways in which these values may be ranked when they conflict, which I will call 'value pluralism'.

24 See, for example, H. Collins, 'European Private Law and the Cultural Identity of States' (1995) 3 European Review of Private Law 353; P. Legrand, 'European Legal Systems are not Converging' (1996) 45 International and Comparative Law Quarterly 52; P. Legrand, 'Antivonbar' (2006) 1 Journal of Comparative Law 13.

25 Cf J. Tasioulas, 'Human Rights, Legitimacy, and International Law' (2013) 58 The American Journal of Jurisprudence 1, 21-22, discussing the value of freedom or sovereignty as a limitation on the legitimacy of international law. My approach has to a large extent been influenced by Tasioulas' important work in the philosophy of human rights and international law.

26 Study Group on Social Justice in European Private Law, 'Social Justice in European Contract Law: a Manifesto' (2004) 10 European Law Journal 653, 654.

27 Ibid 656.

28 Ibid 669. Strictly speaking, I would argue that it is interference with sovereignty which is the relevant concern, not national legal culture or tradition. 


\section{Interpretive pluralism}

By interpretive pluralism, I mean that there are a multiplicity of irreducibly distinct ways to interpret the values that fashion the rules and doctrines of contract law. Take promise as an example. Few would deny that promise or its entailment the protection of the performance interest plays at least some role in contract law. However, even though it plays a role, it does not play a determinate role, ie, it does not specify precisely which rules and doctrines should govern contractual disputes.

To illustrate this, take the example I cited earlier of the purported divergence between English and French law when it comes to awards of cost of cure damages for breach of contract. ${ }^{29}$ It is harder to get cost of cure for breach of a building contract in England, because English contract law imposes a reasonableness requirement. No similar restriction is placed in French law.

Is the imposition of a reasonableness requirement on the recovery of cost of cure damages out of step with the promise principle? Rowan clearly thinks that it is: 'There can be little doubt that the exercise of assessing damages in France is significantly more oriented towards the protection of the performance interest than in England'. ${ }^{30}$ In English law, Rowan argues, the interests of the promisee, 'appear to be subordinated to those of the promisor', ${ }^{31}$ and this leads her to conclude that '... there is scope for improvement in the protection of the performance interest in England' ${ }^{32}$

I am far less certain. In Ruxley, discussed above, instead of awarding cost of cure damages (which would have been $€ 21,560$ ) the House of Lords awarded a smaller sum of loss of amenity damages $(£ 2,500)$ to reflect the promisee's disappointment at not receiving the pool of the specified depth. Given that the pool was still perfectly safe and usable, it's not at all obvious that this decision reflects a lack of concern in English law for the keeping of promises, or the protection of the performance interest. That interest was largely protected in Ruxley: the promisee received a perfectly safe and useable pool, and loss of amenity damages for his frustrated expectations at not receiving a pool that met his exact specifications. $^{33}$

29 Text to notes 2-5 above.

30 Rowan, $\mathrm{n} 4$ above, 118.

31 Rowan, $\mathrm{n} 4$ above, 119.

32 Rowan, $\mathrm{n} 4$ above, 120.

33 See Ruxley, n 3 above, 357: 'A failure to achieve the precise contractual objective does not necessarily result in the loss which is occasioned by a total failure...'. See also M. Chen-Wishart, 
My point here is not to defend the English approach. Rather, it is to suggest that it is far from clear which remedy best protects the performance interest. Promise or the protection of the performance interest does not provide a uniquely correct answer: Cost of cure is a good candidate, but so also is loss of amenity damages. No particular interpretation of the value of promise is obviously right or wrong in this context. ${ }^{34}$

This is true also of other moral values which play a role in contract law, such as fairness, the prevention of exploitation, altruism, corrective justice, and so on. There is no uniquely right way to interpret these values, and they could justify mutually incompatible contract law rules and doctrines.

\section{Value pluralism}

Another source of indeterminacy in contract law is value pluralism. According to value pluralism, there are a multiplicity of irreducibly distinct moral values that play a role in contract law, and no uniquely correct way to rank these values when they conflict. Instead, there exist a variety of eligible combinations. ${ }^{35}$

However, in recent times, there has been an increasing tendency to strongly associate contract law with a particular value at the expense of other values that play a role in shaping doctrine. So, for example, according to the promise theory of contract law, the promise principle, which requires that validly made promises ought to be kept, plays a 'foundational' or special justificatory role, when it comes to fashioning contract law rules and doctrines. ${ }^{36}$

Contract Law ( $2^{\text {nd }}$ ed, Oxford: Oxford University Press, 2005) 531, and P. Saprai, 'Measuring Expectation Damages' (2010) 6 In-Pactum 184, 190-192.

34 Cf Tasioulas, $\mathrm{n} 25$ above, 20, discussing the multiple ways in which the right to political participation might be cashed out. There are he argues a range of eligible interpretations. See also A. Buchanan, 'The Legitimacy of International Law', in S. Besson and J. Tasioulas (eds), The Philosophy of International Law (Oxford: Oxford University Press, 2010) 79, 95: Making the point that people may reasonably disagree about the specific content of even the most fundamental human rights, such as the right not to be tortured.

35 See Tasioulas, $\mathrm{n} 25$ above, 19, discussing the thesis generally, and not, as I do, in the context of contract law. See also L. Green, 'Jurisprudence for Foxes' (2012) 3 Transnational Legal Theory 150, 155-156; J. Waldron, 'Partly Laws Common to All Mankind': Foreign Law in American Courts (New Haven: Yale University Press, 2012) 140, citing R. Dworkin, Law's Empire (Cambridge, Massachusetts: Harvard University Press, 1986) 190-215, and 218-219.

36 S.V. Shiffrin, 'Is a Contract a Promise?', in A. Marmor (ed), The Routledge Companion to Philosophy of Law (New York and London: Routledge, 2012) 241. It is somewhat unclear in the literature what exactly this special role is meant to be. Charles Fried's view in his seminal Contract as Promise: A Theory of Contractual Obligation (Cambridge, Massachusetts: Harvard University 
This view has led the promise theorist Seana Shiffrin to be hugely critical of the Anglo-American regime for breach of contract. She argues that it diverges too significantly from what promissory morality would require. So, for example, as a matter of promissory morality, it is standardly the case that when a promise is broken, the defaulting promisor is required to perform at the next available opportunity. Anglo-American contract law, however, awards expectation damages (the financial equivalent of performance), as the standard remedy for breach, rather than ordering specific performance which would require actual performance. This departure from promissory morality is problematic, she argues, because: 'The law thereby fails to use its distinctive powers and modes of expression to mark the judgment that breach is impermissible as opposed to merely subject to a price', ${ }^{37}$

Shiffrin is similarly critical of the mitigation doctrine, also found in AngloAmerican contract law. According to the doctrine, the victim of a breach of contract has a duty to take reasonable steps to reduce or minimise the loss caused by breach, by for example finding substitute performance. There is divergence here, she claims, with promissory morality where no such requirement exists: 'It is morally distasteful to expect the promisee to do work that could be done by the promisor when the occasion for the work is the promisor's own wrongdoing', ${ }^{38}$

Given the special role that Shiffrin assigns to the promise principle in contract law, it is morally problematic when contract law adopts rules and justifications for rules that directly contradict what promissory morality would require. ${ }^{39}$ This is the basis for her critique of the remedial regime in Anglo-American contract law. Shiffrin does not engage in a comparative exercise, but it is likely, given her

Press, 1981) was that promise plays an exclusive or near exclusive role in contract law. Although in recent work Fried admits that the connection he forged between contract and promise was too tight, see his chapter 'The Ambitions of Contract as Promise', in G. Klass, G. Letsas and P. Saprai (eds), Philosophical Foundations of Contract Law (Oxford: Oxford University Press, 2014) 17. Another candidate is the view that in the contractual context promise has overriding sway when it conflicts with other values. According to Jody Kraus 'Correspondence accounts of the relationship between contract and promise hold either that contract law is justified to the extent it enforces a corresponding moral responsibility for a promise or unjustified to the extent it undermines promissory morality by refusing to enforce a corresponding moral responsibility for a promise'. 'The Correspondence of Contract and Promise' (2009) 109 Columbia Law Review 1603, 1603. For detailed discussion of the various alternatives, see G. Letsas and P. Saprai, 'Contract Law Without Foundations' (unpublished manuscript, on file with authors).

37 S.V. Shiffrin, 'The Divergence of Contract and Promise' (2007) 120 Harvard Law Review 708, 725.

38 Shiffrin, $\mathrm{n} 37$ above, 725.

39 Shiffrin, $\mathrm{n} 37$ above, 717. 
theory, that she would prefer the French regime for breach of contract, where specific performance is the primary remedy for breach of contract, ${ }^{40}$ and where there is no requirement that the innocent victim of breach of contract mitigate his loss. ${ }^{41}$ These differences have led Rowan to conclude that in France 'moral values are integral', whereas English law is more 'commercially orientated' ${ }^{42}$

This type of critique is problematic because it loses sight of other values, aside from promise, which play an important role in justifying remedial doctrines. In a recent article, Charles Fried has accused Shiffrin of exactly this type of moral myopia when it comes to mitigation. That doctrine he claims may be justified by a principle of altruism, activated by the relationship of trust that obtains between the promisor and promisee, and which requires the promisee to assist the promisor where he can do so at little cost to himself. ${ }^{43}$

My aim here is not to adjudicate this dispute between Shiffrin and Fried. Fried is right though to call attention to the fact that there are other values aside from promise, such as altruism, that quite plausibly play a role in shaping contract doctrine. As these values are irreducibly distinct it may be that there is no uniquely correct answer over which of these values should prevail when they conflict. ${ }^{44}$

Indeed, natural lawyers say this kind of indeterminacy, which we find both as a result of interpretive and value pluralism, is precisely why we need positive law. To flesh out or specify the exact requirements of natural reason, and thereby to guide human conduct. That guidance function can't be performed by natural law alone because it is too open to interpretation. As Jeremy Waldron says, 'The concern is to have something tangible, something we can share and look to as a

40 See Rowan, n 4 above, 39-47, 40: 'Unlike in England, specific performance is a central remedy in French contract law'. Standardly specific performance is available as of right in French law (it is a discretionary remedy in English law), even in the context of contracts for the sale of non-unique goods, and building contracts.

41 See Rowan, $n 4$ above, 147-151; S. Le Pautremat, 'Mitigation of Damage: A French Perspective' (2006) 55 International and Comparative Law Quarterly 205.

42 Rowan, n 4 above, 54-54. See also A. Ogus, 'Remedies, English Report', in D. Harris and D. Tallon (eds), Contract Law Today - Anglo-French Comparisons (Oxford: Clarendon Press, 1989) 259, and Miller, n 9 above, 301-307. Rowan is at pains to stress though that this does not mean that moral considerations are not important in England, or that commercial factors don't play a role in shaping French doctrine. There is just a difference in orientation.

43 C. Fried, 'The Convergence of Contract and Promise' (2009) 120 Harvard Law Review Forum 1, 7-8 at http://harvardlawreview.org/2009/10/the-convergence-of-contract-and-promise/ (last visited 15 October 2015).

44 Cf J.M. Finnis, 'On the Critical Legal Studies Movement' (1985) 30 American Journal of Jurisprudence 21,39 . 
point of common orientation' ${ }^{45}$ They call the process by which the law makes natural law concrete the determinatio. ${ }^{46}$ There may be many eligible ways in which the positive law specifies, or renders determinate by case law precedents and legislative enactment, the content of natural law. As John Finnis says using contract law as an example:

one might reasonably defend a set of rules and doctrines authoritatively established in the 'legal materials' (say, the current rules and doctrines of an American law of Contract), and defend them as 'embodying' and 'sustaining' a 'defensible' conception (say, of fair 'market' relationships), without claiming that, in all or even most respects, they are the uniquely reasonable rules and doctrines available for such embodiment and sustenance, or that such a conception is the only 'defensible' conception of a fair market. ${ }^{47}$

The existence of interpretive and value pluralism justify the existence of positive law, and they also explain why state sovereignty is a powerful objection to the EU contract law harmonisation programme.

\section{State sovereignty}

The value of state sovereignty in this context resides in the freedom of states to decide how they interpret and balance the various competing values that fashion contract law rules and doctrines. ${ }^{48}$

As I have said, there are numerous ways in which these values might be legitimately interpreted or balanced. States should, on the whole, be free to decide how to interpret and balance these values. Of course, this does not mean that they can adopt interpretations and rankings that are manifestly unreasonable or unfair. But it does mean that provided that their interpretation or ordering of values falls within a reasonable range, and even in some cases outside of that range, it should be respected even though there may be alternative or even super-

45 J. Waldron, 'Torture, Suicide and Determinatio' (2010) 55 American Journal of Jurisprudence 1, 10. See also Tasioulas, n 25 above, 17: 'when reason leaves a number of interpretations open, reason itself can demand an act of individual or collective will to identify the one that is to serve as a basis for co-ordination'.

46 Waldron, n 45 above, 2, 9; Finnis, n 44 above, 23; H. Collins, 'Cosmopolitanism and Transnational Private Law' (2012) 8 European Review of Contract Law 311, 314.

47 Finnis, $n 44$ above, 23, and see 37-38.

48 Cf Tasioulas, $\mathrm{n} 25$ above, 21-22, discussing the value of freedom or sovereignty as a limitation on the legitimacy of international law. 
ior interpretations and orderings. This is because of the instrumental and intrinsic value of states making these choices freely. ${ }^{49}$

The instrumental value rests in the fact that states may be better placed to fashion contract law rules and doctrines that meet local needs and expectations. ${ }^{50}$

Furthermore, as Timothy Endicott reminds us, external actors 'are not generally good at interfering with the state'. ${ }^{51}$ For these reasons, the rules that a state itself creates may be more likely to promote valuable goals and ends, and achieve widespread acceptance from the local population, which is essential for their efficacy and legitimacy.

This freedom also has an intrinsic value. ${ }^{52}$ The choices that states make about how these values are interpreted and ranked may help to forge and express a sense of national identity. As Hugh Collins has argued, different systems of private law reflect distinct mixes of values relating, for example, to autonomy, welfare and externalities. These mixes amount to national political settlements on matters of social justice, which confer legitimacy on these systems of private law, and reflect a sense of collective identity that promotes community cohesion. ${ }^{53}$

Similarly, the Study Group on Social Justice in European Private Law says 'private law still performs its role as a national statement of the basic principles of justice and social ordering in a market society', ${ }^{44}$ and 'what is revealed by comparative studies is that national legal systems have made divergent political decisions with respect to the question of how basic values should be reconciled'. ${ }^{55}$

I agree with Collins and the Study Group here that private law involves the choice between fundamental values, and that this plays a role in constituting national identity. However, the focus on politics and social justice in these passages is too narrow. The widespread presence of interpretive and value pluralism allows for the expression of a broader set of commitments. So, for example, French contract law expresses vividly the importance keeping one's word. This may be the product of a political compromise, but it may also reflect something deep in the French psyche that goes well beyond the domain of politics or social justice.

49 Tasioulas, n 25 above, 20; J. Tasioulas, 'The Legitimacy of International Law', in Besson and Tasioulas (eds), n 34 above, 97, 113; T. Endicott, 'The Logic of Freedom and Power', in Besson and Tasioulas (eds), n 34 above, 245, 255.

50 Tasioulas, $\mathrm{n} 49$ above, 106.

51 Endicott, $\mathrm{n} 49$ above, 255.

52 Tasioulas, $\mathrm{n} 25$ above, 20.

53 Collins, n 46 above, 320-321.

54 Study Group on Social Justice in European Private Law, n 26 above, 654.

55 Ibid 663. 
Take the doctrine of mitigation, which I discussed earlier. As I pointed out, unlike in English law, there is no duty on the promisee to mitigate loss for breach of contract in French law. It may be that both of these alternatives, ie, having a mitigation requirement or not having one, are equally rational or based on undefeated reasons. However, whether a state chooses to lay down a mitigation doctrine expresses something about the national character of that state, ie, the values, beliefs and ideals that it attaches particular importance to. By embracing mitigation it may be that the English courts attach less priority to the promise principle, and more to values such as altruism, loss avoidance or fairness. ${ }^{56}$ However, in France greater priority may have been attached to the value of fidelity to one's promises. This is not merely a political value, but one that reaches into every corner of life. By not having a mitigation doctrine, the promisor is incentivised to perform. Either way, one value is justifiably sacrificed at the altar of another.

As the values at stake are incommensurate, or irreducibly plural, no particular ordering of these values is uniquely correct. ${ }^{57}$ Rationality under-determines whether the promisee should be required to mitigate. Rather, national courts or legislators are faced with a choice between undefeated reasons. So, for example, they can either promote a value like altruism or fairness by requiring the promisee to mitigate, or they can incentivise promise-keeping by imposing no such duty. Which of these undefeated reasons the state chooses to act on says something about the national character of that state. It is a form of boundary marking, and as Joseph Weiler has argued this is how a sense of nationhood is fostered:

At a societal level, nationhood involves the drawing of boundaries by which the nation will be defined and separated from others. The categories of boundary-drawing are myriad: linguistic, ethnic, geographic, religious, etc. The drawing of the boundaries is exactly that: a constitutive act, which decides that certain boundaries are meaningful both for the sense of belonging and for the original contribution of the nation... Of course, with time, the boundaries, especially the non-geographical ones, write themselves on collective and individual consciousness with such intensity that they appear as natural... ${ }^{58}$

56 See C. Goetz and R.E. Scott for a loss avoidance justification of mitigation: 'The Mitigation Principle: Toward a General Theory of Contractual Obligation' (1983) 69 Virginia Law Review 967, 973. And see G. Letsas and P. Saprai for a fairness-based justification: 'Mitigation, Fairness, and Contract Law', in Klass, Letsas, and Saprai (eds), n 36 above, 319.

57 As Herbert Hart said, 'because a plurality of such principles is always possible it cannot be demonstrated that a [judicial] decision is uniquely correct...'. H.L.A. Hart, The Concept of Law ( $3^{\text {rd }}$ ed, Oxford: Oxford University Press, 2012) 205, cited by Green, n 35 above, 155.

58 J.H.H. Weiler, The Constitution of Europe (Cambridge: Cambridge University Press, 1999) 340. 
For Weiler nationhood creates a sense of belonging and provides an opportunity for the development of original ways of realising human potential. Nationhood arises partly out of the kind of boundaries that are drawn when states make choices between values. ${ }^{59}$ In the legal context, these choices are made when judges decide cases, when politicians enact legislation and when scholars write textbooks. As Hesselink comments, 'scholars and politicians do not find national private law but create it'. ${ }^{60}$ Over time when a sense of nationhood takes root it may actually determine how a state exercises these choices. It might require a court or a legislator to select certain values over others. ${ }^{61}$

In this way a sense of national identity is forged, reflected and expressed by the rules, principles and doctrines that constitute national private law. This can only happen if states are free from external interference when it comes to making decisions about how values should be interpreted and balanced. ${ }^{62}$ The nation has a moral right to self-determination in this sphere. That right is a ground, or justification, for the doctrine of state sovereignty. ${ }^{63}$

One objection might be that if the concern is with self-determination, it may be a problem for this argument that most decisions about the rules and doctrines of national private law are made by un-elected judges, or, in states with civil codes, by committees of jurists. The thought is that for the argument from selfdetermination to have any purchase, these decisions should have been taken democratically or by elected officials. ${ }^{64}$ The fact that citizens did not have a say in these rules diminishes the argument that external interference with them compromises the right to self-determination. ${ }^{65}$

For two reasons, this line of attack is not convincing. First, self-determination should not be equated with democracy. As Waldron says: 'The right of self-

59 As Michael Green says '[a] civilization... attempts to melt down different peoples, ethnic groups, and cultures who do not share the same fundamental beliefs, values and attitudes into a common framework of beliefs and values'. Quote from 'Codes of Civilization and Codes of Culture', in R. Kevelson (ed), Codes and Customs (New York: Peter Lang, 1994) 112. Cited by P. Legrand, 'Against a European Civil Code' (1997) 60 Modern Law Review 44, 61. See also K. W. Deutsch, Nationalism and Social Communication: An Inquiry into the Foundations of Nationality ( $2^{\text {nd }}$ ed, Cambridge: MIT Press, 1966).

60 Hesselink, $n 18$ above, 345.

61 J. Tasioulas, 'Mercy' (2003) 103 Proceedings of the Aristotelian Society 101, 128-132.

62 Tasioulas, $\mathrm{n} 49$ above, 112.

63 Tasioulas, n 49 above, 113; Endicott, n 49 above, 255.

64 Thanks to Dan Priel and Octavio Ferraz for pressing me on this point.

65 In the case of civil codes, Reinhard Zimmermann claims that citizens are largely unaware of their provisions and characteristics: 'Codification: The Civilian Experience Reconsidered on the Eve of a Common European Sales Law' (2012) 8 European Review of Contract Law 367, 380. 
determination is prior to democracy, for it includes the right to decide whether to have a democracy around here, and if so, what sort of democracy to have'. ${ }^{66}$ Second, even when officials are unelected, they may nevertheless be acting on behalf of a certain society or nation, or at the least reflect in their decision-making a sense of national consciousness or priorities. In this way, they can still express the will of the people that they serve, and indeed play a role in shaping and forging it. For these two reasons, outside interference with this kind of decisionmaking may be problematic from the perspective of the right to self-determination, whether or not these decisions are the product of democratic processes.

In summary, sovereignty protects the valuable freedom of states to interpret and rank the values that play a role in contract law. This is in part how collective or national identities are forged, and it is important for the efficacy and legitimacy of systems of national private law. It is this background doctrine of state sovereignty, which activates the central problem of legitimacy, to which I shall now turn.

\section{Legitimacy}

\section{The nature of legitimacy}

In the previous section, I defended the doctrine of state sovereignty when it comes to decision-making about the rules and doctrines of national contract law. I based the defence on the moral right to national self-determination. It is this defence of state sovereignty which gives rise to the problem of the legitimacy of the EU's project to bring about the convergence of contract law through the DCFR. The pertinent question is can the EU justify its interference with national sovereignty in this particular domain? Another way of putting this is whether the EU has established the right to rule in this area, ie, the right to lay down authoritative directives which when exercised Member States have a moral duty to obey? ${ }^{67}$

There is of course an immediate objection to the way I have set up the problem of legitimacy here. It assumes the Westphalian primacy of the sovereign state, when arguably the EU is a transnational enterprise. In a recent article, Neil Walker sets out the various competing conceptions of what the EU is:

66 J. Waldron, 'Two Conceptions of Self-Determination', in Besson and Tasioulas (eds), n 34 above, 397, 408.

67 Tasioulas, n 49 above, 97-98, drawing on J. Raz, The Morality of Freedom (Oxford: Clarendon Press, 1986) ch 2, and J. Raz, 'The Problem of Authority: Revisiting the Service Conception' (2006) 90 Minnesota Law Review 1003. 
They are, in turn, a neo-federalist position, treating Europe's destiny as involving some approximation of a continental state. At the other extreme, is a statist position, which comprehends the European good as ultimately reducible, rather like the typical international regime, to the inter-governmentally negotiated aggregate interests of the Member States. Located between these two, is a supranational, or in some conceptions, transnational position, which envisages the new Europe not as a trade-off between different levels of state or state-like authority but as transcending the logic of statehood in a new model of political design. ${ }^{68}$

It is beyond the scope of this paper to evaluate these rival interpretations. Instead, I do indeed assume here that the nation state is the basic political unit in the EU context. With that in mind, my analysis of legitimacy is traditional from the point of view of international law theory, and aimed primarily at the two extremes presented by Walker, namely the 'neo-federalist' and 'statist' positions. Inevitably, this leaves my presentation of the issues open to the criticism that the EU is a tertium quid. ${ }^{69}$ I concede that this is a limitation of my argument.

In defence of my approach, there is value in highlighting what the legitimacy constraints are from the point of view of orthodox international law theory, according to which, the EU is an international organisation born of international law (albeit one that is unprecedented in its scale, scope and powers). I would make three points. First, understanding the legitimacy constraints such a conception faces is important, because the neo-federalist and statist interpretations have been incredibly influential. ${ }^{70}$

68 N. Walker, 'The Philosophy of European Law', in D. Chalmers and A. Arnull (eds), The Oxford Handbook of European Union Law (Oxford: Oxford University Press, 2015) 3, 7-8 (footnote omitted).

69 For a sophisticated defence of this conception see J.H.H. Weiler and U.R. Haltern, 'Constitutional or International? The Foundations of the Community Legal Order and the Question of Judicial Kompetenz-Kompetenz', in A.-M. Slaughter, A.S. Stewart and J.H.H. Weiler (eds), The European Courts and National Courts: Doctrine and Jurisprudence (Oxford: Hart Publishing, 1998) 331.

70 Varieties of the neo-federalist position were held by two of the founding fathers of the project, Jean Monnet and Robert Schuman. See Walker, n 68 above, 8-9. See also F.G. Jacobs and K. L. Karst, 'The "Federal” Legal Order: The U.S.A. and Europe Compared - A Juridical Perspective', in M. Cappelletti, M. Seccombe and J. Weiler (eds), Integration Through Law: Europe and the American Federal Experience (Berlin \& New York: Walter de Gruyter, 1986) 169. Statism has a long pedigree in the tradition of German ordoliberalism, according to which 'Europe should be no more than a delegated market-making framework, enhancing the common pool of resources and economic welfare of all Member States...'. Walker, n 68 above, 9. For a recent defence of the statist picture see B. De Witte, 'The European Union as an International Legal Experiment', in G. De Búrca (ed), The Worlds of European Constitutionalism (Cambridge: Cambridge University Press, 
Secondly, as Walker stresses, this trio of approaches are not hermetically sealed off from one another, but exist along a spectrum. ${ }^{71}$ Although the wind now is certainly behind the transnational understanding,${ }^{72}$ no plausible account of the EU could ignore the political reality of the importance attached to state sovereignty in the EU context. Indeed, as Perry Anderson argues, historically at the heart of the very idea of Europe is a 'unique equilibrium' between its constituent states. ${ }^{73}$ Therefore, the legitimacy constraints imposed by state sovereignty, are to some degree going to be relevant whichever approach to the EU is undertaken.

Finally, the transnational approach is far from achieving a settled understanding; it is highly contested what the conception is, and against that background it makes sense to begin legitimacy assessments with the neo-federalist and statist positions which are well established and better understood.

Another objection might be that it makes no sense to subject contract law alone in this context to a legitimacy assessment. Allen Buchanan has argued that when making legitimacy assessments the primary issue is whether a particular legal institution, such as the EU, is legitimate, because that is what the legitimacy of all of its particular laws depends on. ${ }^{74}$ On his view, 'international laws are legitimate only if the institutions that make them are legitimate' (my emphasis). ${ }^{75}$ This view is too strong, and indeed mistaken. There is of course a huge literature on the issue of the legitimacy of the EU, about its 'democratic deficit', and so on. It seems clear that this question about the legitimacy of the EU as a whole is separate from the question about whether the EU has legitimacy in particular spheres, for example, labour law, environmental protection, consumer law, and so on. The fact that we constantly make legitimacy assessments in these particular contexts, and that they seem perfectly apt, bears this out. Therefore, it seems that whatever the case may be with respect to whether the EU as an institution is legitimate, it is a further question whether the EU's attempts to harmonise contract law are legitimate. ${ }^{76}$

2012) 19. And see T.C. Hartley, 'International Law and the Law of the European Union - A Reassessment' (2002) 72 The British Year Book of International Law 1.

71 Walker, $\mathrm{n} 68$ above, 8.

72 Ibid; De Witte, n 70 above, 20; S. Douglas-Scott, Constitutional law of the European Union (London: Longman, 2002) 260.

73 P. Anderson, The New World Order (London: Verso, 2009) 477. See also Walker, n 68 above, 6: 'the political recognition of Europe as a discreet object could only be of an entity whose basic structure and distinctive configuration was one of prior and embedded political plurality'.

74 Buchanan, $\mathrm{n} 34$ above, 79-80.

75 Buchanan, $\mathrm{n} 34$ above, 80.

76 Cf Tasioulas, n 49 above, 102-103, and 103 footnote 13 suggesting, furthermore, that the legitimacy of domains may actually be primary. See also the distinction between 'integrated' and 'disaggregated' approaches to legitimacy in Walker, n 68 above, 12-15. 
It is important to stress that the issue of the legitimacy of the EU's contract law harmonisation programme does not exhaust the normative questions that arise in this context. It is a separate question, for example, whether the content of the rules contained in the DCFR is just, efficient, and so on. Therefore, even if we reach the conclusion that the process is legitimate, ie, that the EU has the right to lay down authoritative directives with a view to bringing about the convergence of contract law in Europe, this does not mean that the EU should legislate in this area. In the last section of this article, I will illustrate this by considering the issue of the efficacy of the programme. ${ }^{77}$

That said legitimacy does play a special role in debates about convergence. It functions to borrow Robert Nozick's famous phrase about rights as a 'sideconstraint'. ${ }^{78}$ By this I mean that we have to settle the issue of the legitimacy of the contract law harmonisation programme before we get into the question of whether convergence would be a good idea. It functions as a threshold: no matter what convergence has going for it, it is not something that the EU can pursue, if it does not have legitimate authority in this sphere. In the next section, I will consider what the conditions of legitimacy are in this context, and raise some preliminary doubts about whether they have been satisfied. As I said earlier though, it is not my purpose to engage in a full-scale legitimacy assessment in this context.

\section{The conditions of legitimacy}

Having established the nature of legitimacy, and the fact that it applies to domains as well as institutions, we can now investigate the conditions of legitimacy, ie, the circumstances under which a right to rule exists.

There are, of course, many competing theories of what the conditions of legitimacy are. I am going to consider four influential accounts, which all seem to be salient in this particular context. They are legitimacy as consent, Joseph Raz's Normal Justification Thesis ('NJT'), legitimacy as democracy and legitimacy as fairness. Whichever theory we look at, the legitimacy burden is significant, and I will express some doubts about whether it has been satisfied.

77 The point I am making here is a general one: the existence of a right does not entail that it should be exercised.

78 R. Nozick, Anarchy, State, and Utopia (Oxford: Blackwell, 1974) 28-30. 


\section{(a) Consent}

The literature on the legitimacy of the convergence of contract law in Europe has focused almost exclusively on the issue of constitutional legitimacy, or whether Member States have consented to give away their sovereign rights in this sphere by signing up to and ratifying various EU treaties. This illustrates the importance still attached to state sovereignty, and no doubt reflects the fact that consent has been the central plank of the European Commission's own justification for its legitimacy in this field.

Nevertheless, giving consent pride of place in these debates is completely unwarranted. This is for two reasons. First, the claim that Member States when they signed these treaties consented to the prospect of the convergence of the general law of contract in Europe is completely implausible. The Treaty on the Functioning of the European Union (TFEU) provides no explicit mandate for a contract law harmonisation programme. Instead, the Commission has sought to establish competence on the basis of provisions, in particular Article 114 TFEU, ex Article 95 Treaty Establishing the European Community (TEC), relating to the promotion of an internal market. However, it seems unlikely in the extreme that when states agreed to these, they ever envisaged that they could be used by the Commission to embark on a programme for the harmonisation of the general law of contract. Given this, it cannot be said that states consented. ${ }^{79}$

There is a second, much more fundamental point. Even if, contrary to the political reality, states did consent to the contract law harmonisation process, this would not establish the legitimacy of the Commission's programme. Consent is neither a necessary, nor a sufficient condition for the legitimacy of international law. ${ }^{80}$ The existence of customary international law shows that consent is not necessary. There are states that did not even exist when some of these customs emerged, and yet, even though they could not possibly have consented, they are nevertheless subject to them. ${ }^{81}$

Nor is consent sufficient for legitimacy. As Scott Hershovitz has argued, consenting to be subject to the dictates of a wicked authority 'is akin to promising to do something morally atrocious; neither generates the reasons it might under

79 This raises the more general problem of what Buchanan calls the 'bureaucratic distance' between states that have by treaty established global governance institutions like the EU and the continuous rule-making activities that these institutions engage in. To say that states have consented to all of these individual acts of rule-making unduly stretches the notion of consent. Buchanan, $\mathrm{n} 34$ above, 91.

80 See Buchanan, $\mathrm{n} 34$ above, 90-93.

81 Buchanan, n 34 above, 92. 
more felicitous conditions'. ${ }^{82}$ So, in the international context if states enter into a treaty to wage an unjust war, that treaty would lack legitimacy regardless of consent.

I am not saying that consent plays no important role or is altogether irrelevant to assessments of legitimacy. Obviously, that would be too strong. Rather, the point is that it is not a fundamental condition of legitimacy. This does not preclude saying that it plays a derivative role, in relation to the fulfilment of the true or more basic conditions of legitimacy. ${ }^{83}$

For these reasons, consent does not even get off the ground as a plausible basis for legitimacy in this context. I am now going to focus on some more plausible conceptions of the conditions of legitimacy.

\section{(b) The normal justification thesis}

Joseph Raz argued famously that although there is no single test of the legitimacy of an authority, typically it is a sufficient condition for the legitimacy of an authority if it satisfies what he called the Normal Justification Thesis (NJT):

the normal way to establish that a person has authority over another person involves showing that the alleged subject is likely better to comply with the reasons which apply to him (other than the alleged authoritative directive) if he accepts the directives of the alleged authority as authoritatively binding and tries to follow them, rather than by trying to follow the reasons which apply to him directly. ${ }^{84}$

In essence, the question is: are we better off following the authority, than by following our own lights about how to act? ${ }^{85}$ This forms part of what Raz calls the 'service conception of authority'. Authorities are legitimate on this view when they serve the interests of their subjects by enabling them to better conform to reasons that they already have.

In the context of the convergence of contract law, the relevant subjects of the authority of the EU are primarily Member States (and indirectly their citizens). ${ }^{86}$ This goes back to the assumption I made earlier that the nation state is the basic political unit in the EU context, which reflects, I believe, the political reality. From the perspective of the NJT, the relevant question here is: do Member States better

82 S. Hershovitz, 'Legitimacy, Democracy, and Razian Authority' (2003) 9 Legal Theory 201, 215.

83 Tasioulas, $\mathrm{n} 49$ above, 101-102.

84 Raz (1986), n 67 above, 53.

85 Hershovitz, $\mathrm{n} 82$ above, 206.

86 Cf Buchanan, n 34 above, 85. 
conform with reasons that they already have if they go along with a programme for the harmonisation of contract law, than by continuing to apply their own contract law?

There are two candidate reasons in this context that apply to all Member States that might justify the authority of the EU in this sphere. The first is the promotion of cross-border trade, and the second is ensuring justice in the settlement of contractual disputes. I will consider both below, and express some doubts about whether greater conformity with these reasons would be achieved by convergence.

\section{(i) Promoting cross-border trade}

The economic case for convergence is well known. It is the basis of the Commission's own case for harmonisation, and it is usually put in terms of consent. The argument is straightforward. The divergence between the contract law regimes of Member States of the EU is a significant barrier to cross-border trade. ${ }^{87}$ Convergence would remove these barriers. Therefore, under Article 114 TFEU (ex Article 95 TEC), the Commission has legitimate authority to harmonise contract law, in order to bring about an integrated market.

For the reasons that I have already given, this argument will not work. It is artificial to say that Member States consented to the convergence of contract law, and even if they had, consent is not a fundamental condition for the legitimacy of international law.

However, it might be possible to rescue the economic case using the NJT. Member States have strong reasons to promote cross-border trade. These relate in particular to the furtherance of peace and prosperity between nations.

Assuming that the convergence of contract law in Europe would promote cross border trade, the EU's programme might satisfy the NJT on the basis that only through the EU is co-ordinated action to bring about convergence possible. This is due mainly to the tendency of Member States to obey EU directives. For this reason states are more likely to conform to the reasons they already have to promote peace and prosperity if they follow the directives of the EU in this area, rather than try to bring about convergence themselves. ${ }^{88}$

87 Commission, 'Action Plan' (2003), n 11 above, paras 25-51.

88 Tasioulas calls this an 'executive' advantage that public international law may have. It arises from its ability in certain cases to bring about the achievement of common goals, due to the tendency of states to comply with it: 'All states face problems - epidemics, economic instability, environmental degradation, the proliferation of weapons of mass destruction, refugee move- 
Whether the NJT is satisfied in this context depends on the strength of the economic case for convergence. It is beyond the scope of this paper to provide a full-scale economic analysis of the issues. Indeed, much depends on the method of convergence adopted. There is a nascent literature on this topic, and it is fair to say that the jury is still out. ${ }^{89}$ However, I will express some preliminary doubts about the economic arguments the Commission itself has put forward, if only to show that the economic case is far from obvious. As such, it is a risk to base the case for convergence on these economic arguments alone.

The Commission claims that there are two main ways that divergence inhibits cross-border trade. First, divergence discourages consumers from shopping across borders, because they cannot be sure what level of consumer protection they will receive in the state in which they are making a purchase. The EU has relied on this argument in the past to justify directives that aim to harmonise consumer law, ${ }^{90}$ and it was used recently to justify the review of the consumer acquis. ${ }^{91}$ The basic idea, according to Lucinda Miller, is that 'the EU steps in to reduce such unequal substantive rights by (re)regulating consumer contract law in the form of harmonising Directives thereby restoring the confidence of consumers to shop in other EU states'. ${ }^{92}$

Second, divergence by creating legal uncertainty deters businesses, due to higher transaction costs, from engaging in cross-border trade. In a recent article, Hugh Beale, a leading figure in the preparation of the DCFR, fleshes out the worry:

ments, etc - that cannot be adequately addressed by individual states acting alone but only through a framework for co-operation and co-ordination. PIL can provide such a framework, largely in virtue of the propensity of states to obey it', n 49 above, 102.

89 See for example G. Wagner, 'The Economics of Harmonisation: The Case of Contract Law' (2002) 39 Common Market Law Review 995; F. Gómez, 'The Harmonization of Contract Law through European Rules: A Law and Economics Perspective' (2008) 4 European Review of Contract Law 89; O. O'Connor, 'The Limits of Contract Law Harmonisation' (2012) 33 European Journal of Law \& Economics and contributions to a special issue of the Common Market Law Review on the theme of economic approaches to European contract law: (2013) 50 (1/2) Common Market Law Review.

90 See for example Recital 5 of the Council Directive 99/44/EC on Certain Aspects of the Sale of Consumer Goods and Associated Guarantees [1999] OJEC L171/12: 'Whereas the creation of a common set of minimum rules of consumer law, valid no matter where goods are purchased within the Community, will strengthen consumer confidence and enable consumers to make the most of the internal market'. Cited by Miller, $\mathrm{n} 21$ above, 49.

91 See the Commission Green Paper on the Review of the Consumer Acquis COM(2006) 744 final, 4. Cited by Miller, n 21 above, 49. See also recital 6 of the Council Directive 2011/83/EU on Consumer Rights [2011] OJEC L 304/64.

92 Miller, $\mathrm{n} 21$ above, 49. 


\begin{abstract}
it seems self-evident that having to deal with a variety of legal systems must add to the cost, or the risk, of anything except the simplest cross-border transaction. The business will want to know, what difference will it make to us if the other party insists on the contract being governed by their law (or indeed the law of some third country)? Will our standard contract 'work' as well under that law as it does under our own law? Perhaps even more important is that for many business people, differences between legal systems create a psychological barrier. $^{93}$
\end{abstract}

So, for example, in the context of business-to-consumer transactions, businesses that sell their goods across borders are subject to the consumer protection laws of each member state in which they operate: ${ }^{94}$

This means that a business advertising its goods across Europe, for instance via a website 'eshop', must be prepared to deal with the consumer protection rules of at least 28 different jurisdictions. ${ }^{95}$

Beale argues that these problems pose a particularly acute challenge to small and medium-sized enterprises, which do not have access to the same legal expertise about foreign law as bigger firms, and don't have the resources to take the same risks that larger firms can. ${ }^{96}$

These twin concerns about consumer confidence and the effects on business are the foundation of the EU's justification for its programme of contract law harmonisation. ${ }^{97}$ They were re-iterated recently in Recital 7 of the Proposal for a Directive on Consumer Rights:

93 H. Beale, 'A Common European Sales Law (CESL) for Business-to-Business Contracts', in L. Moccia (ed), The Making of European Private Law: Why, How, What, Who (Munich: Sellier, 2013) 65, 67. See also H. Collins, 'Harmonisation of European Contract Law: Citizenship, Diversity and Effectiveness' (2004-2005) 7 Cambridge Yearbook of European Legal Studies 81, 94, arguing that a significant obstacle to trade in the EU is the fact that different Member States adopt different rules about when standard form contracts are enforceable or valid. This creates uncertainty for businesses engaged in cross-border trade. See O. Lando, 'Is Codification Needed in Europe? Principles of European Contract Law and the Relationship to Dutch Law' (1993) 1 European Review of Private Law 157; Commission, 'Action Plan' (2003), n 11 above, paras 27-51.

94 This is due to art 6, Council Regulation (EC) 593/2008 on the law applicable to contractual obligations (Rome 1) [2008] OJEC L177/6.

95 Beale, $\mathrm{n} 93$ above, 65. See similarly Wagner, n 89 above, 1013-1014: 'It should be obvious that such a state of affairs places additional costs on the dealings of a truly European enterprise marketing its goods and services in every jurisdiction of the Union... it is no exaggeration to say that legal diversity places a tax on European business, a tax that creates no benefits either for firms or for consumers but only benefits for lawyers'.

96 Beale, n 93 above, 67. See also Wagner, n 89 above, 1014-1015; Beale, n 23 above, 270-271; Hesselink, n 18 above, 353.

97 Miller, $\mathrm{n} 21$ above, 59. 
These disparities create significant internal market barriers affecting business and consumers. They increase compliance costs to business wishing to engage in cross border sale of goods or provision of services. Fragmentation also undermines consumer confidence in the internal market. The negative effect on consumer confidence is strengthened by an uneven level of consumer protection across the Community. ${ }^{98}$

And yet, as Miller has pointed out, these arguments are almost entirely 'underanalysed' and routinely taken for granted in the academic literature. ${ }^{99}$ If we scratch beneath their surface, two problems come into view.

First, as Miller says, there is an 'astonishing' lack of empirical evidence provided by the Commission to support the contention that divergence negatively impacts cross-border trade: ${ }^{100}$ 'Instead, the assumption that variations in contract laws do create obstacles to cross-border trade transactions is allowed to remain unproven.... ${ }^{101}$

This is particularly problematic given that we know that trade has flourished between jurisdictions with divergent contract laws. Think, for example, of trade between England and Scotland, or between American states. ${ }^{102}$

This experience suggests, at the very least, that it is unclear that differences in legal rules necessarily inhibit cross-border trade. It may well be that other factors such as linguistic and cultural differences, or absence of trust in legal enforcement mechanisms in other jurisdictions, or the practicalities of pursuing redress abroad, play a more significant role. ${ }^{103}$

Even if empirical evidence were available to support the claim that divergences in contract law were a significant deterrent to cross-border trade, there is a second problem with the economic case. The fact that divergence may be a barrier to cross border trade does not necessarily mean that the general law of contract should converge throughout Europe.

As has been pointed out by the Study Group on Social Justice in European Private Law, there are less drastic solutions. First, certain areas of contract law, such as the sale of goods, commercial law and consumer law, are more likely to

$98 \operatorname{COM}(2008) 614$ final. Cited by Miller, $\mathrm{n} 21$ above, 60.

99 Miller, $\mathrm{n} 21$ above, 59.

100 Miller, $\mathrm{n} 21$ above, 60.

101 Miller, n 21 above, 60-61. See also: Wagner, n 89 above, 1016; Gómez, n 89 above, 109-111, 115; European Union Committee on European Contract Law, n 22 above, para 83. The criticism has been acknowledged by Hugh Beale, 'Finding the Remaining Traps Instead of Unifying Contract Law', in S. Grundmann and J. Stuyck (eds), An Academic Green Paper on European Contract Law (The Hague: Kluwer Law International, 2002) 67.

102 Miller, $\mathrm{n} 21$ above, 61.

103 Miller, n 21 above, 62-63; Wagner, n 89 above, 1016-1017; Zimmermann, n 65 above, 391; European Union Committee on European Contract Law, n 22 above, para 51. 
be affected by these kinds of economic concerns than others. Therefore, whilst there may be a case for a sector-specific harmonisation of contract law, it is difficult to extend that economic argument to justify the convergence of the whole of contract law in Europe. Secondly, many of the problems thrown up by divergence can already be solved by market actors through, for example, the use of choice of law clauses. By altering their contracts 'traders can avoid most potential barriers to cross-border commerce'. ${ }^{104}$

Hence, it is unclear why even if divergence is problematic on economic grounds, the solution proposed is the harmonisation of the general law of contract. The Commission seems to want to use a sledgehammer to crack a nut. ${ }^{105}$

These two flaws, that it is uncertain that divergence is a barrier to crossborder trade, and that even if it is, it is unclear that the convergence of the general law of contract is the solution, suggest that the economic case may not satisfy the NJT test for legitimacy. It cannot be said with confidence that the EU harmonisation programme is likely to lead Member States to greater conformity with their reasons to promote cross-border trade, than if they pursue these objectives directly. As I said, I cannot engage in a full-scale analysis of the economic issues here, but these doubts about the case the Commission itself has presented, show that there is further work here that needs to be done.

\section{(ii) Achieving Justice}

Another set of reasons that clearly apply to states and which seem relevant in this context are reasons of justice. In particular, reasons to ensure that contract disputes are settled correctly. It could be argued that contract law harmonisation helps to achieve this objective.

This kind of claim is supported by the prevailing 'functionalist' view that national differences between legal concepts, rules, and doctrines mask the fundamental similarity between the facts and outcomes of cases. As Beale puts it: 'for the most part the laws do reach rather similar results; the problem is one of translation between differing terminology and conceptual structures' ${ }^{106}$

104 Study Group on Social Justice in European Private Law, n 26 above, 656.

105 This has led the Study Group to be suspicious of the motives of the Commission. They worry that the economic case may be a Trojan horse for a broader political agenda. Study Group on Social Justice in European Private Law, n 26 above, 656-657.

106 Beale, $n 23$ above, 268. 
On this view, most differences in the laws of Member States are not substantive in nature, and the role of the DCFR is to seek out 'the 'best' of the national approaches to achieve a particular policy outcome' ${ }^{107}$

However, as I have argued, the existence of widespread interpretive and value pluralism challenges the notion that there can be one 'best' solution to a legal problem. Rather, there may be multiple eligible ways of solving a particular dispute. In that light, the DCFR and the harmonisation process of which it forms a part begins to look problematic. One 'best' solution is being imposed on all Member States, even though the solutions that they have already adopted are rationally defensible, or based on undefeated reasons. Against this background, interference appears illegitimate. ${ }^{108}$

The problem creates tension between Member States and the EU, because these distinct solutions reflect distinct value judgments. In his evidence to the House of Lords European Union Committee Stefan Vogenauer said that there are fundamental differences of ethical outlook between English contract law and the DCFR framework: 'The model of English contract law is a bargain between the parties who are essentially at arm's length'. In contrast, the DCFR 'would provide a less commercial, less hardnosed contract law, a contract law that is more open to considerations of substantive justice and fairness.... ${ }^{109}$

This has led to the worry in political circles in England that harmonisation is a threat to the values of predictability, certainty and clarity that English contract law is thought to instantiate. ${ }^{110}$ I have already explained the valuable role that these value judgments play in the creation and expression of national identity.

It may be argued that although it is true of some Member States that their contract laws reflect eligible orderings of values, it is not true of all states, and this might justify harmonisation. So, for example, Vogenauer suggested to the House of Lords European Union Committee that Eastern European states in particular may have had strong incentives to promote the development of the DCFR due to the need to break from their socialist pasts:

Imagine you were in a transition country in around 2000 and you were still stuck with a civil code that was either enacted during the socialist period or that predates the socialist period, is often based on German law or Austrian law, but has been interpreted for 30 years in a socialist mode, then you would have a very strong incentive to reform your contract law and

107 Beale, $\mathrm{n} 23$ above, 268.

108 Tasioulas, $\mathrm{n} 49$ above, $109-110$.

109 European Union Committee on European Contract Law, n 22 above, Minutes of Evidence 13. 110 R. Sefton-Green, 'French and English Crypto-Nationalism and European Private Law: An Exercise in Sentiment and Reason' (2012) 3 European Review of Contract Law 260, 272, quoting Lord Falconer. 
bring it to Western standards, standards that cherish party autonomy, freedom of contract and break with a socialist understanding of a contract that really sees the contract as an instrument in promoting the overall general good of the socialist society. ${ }^{111}$

Arguably, these Eastern states may have reason to go along with the DCFR framework, compared to Western states, such as England and France, where there is no similar need to update the existing contract law regimes. This brings out the relational character or subject specificity of the NJT. ${ }^{112}$ It may be that the EU in this sphere has legitimate authority with respect to some states, ie, those that need to reform their contract law, but not with other states that have no such need.

However, this creates a patchwork, which does not go far enough. The EU is seeking to establish its legitimacy in this sphere with respect to all Member States, not just those few that need to reform their regimes. To do this, there has to exist a common reason or set of reasons that apply to all Member States, conformity with which will be furthered by harmonisation. Given, as I have argued, that there are many rationally defensible contract law regimes, how can there be a justicerelated reason to promote convergence?

One reply might be that states have a reason not only to ensure justice within their own borders, but abroad too. ${ }^{113}$ This is most obviously true in the context of international human rights law. Even states that have a good record in upholding human rights have a reason to follow international standards in this domain in order to ensure that human rights are upheld in states that have poor records. ${ }^{114}$ Similarly, it could be argued in the context of contract law that Western states have good reason to subject themselves to the EU harmonisation process, so that contract law disputes in, say, former socialist states where there is a need to reform are handled better.

However, the analogy rings hollow. Human rights law engages our deepest and most urgent interests, freedom from torture, slavery, freedom of thought, expression, and so on. Due to this, we have duties to ensure that these freedoms are upheld not only in our own state, but also beyond our borders. The same cannot be said for contract law rights. The interests protected by these rights are not pressing in the same way, and for that reason we do not have sufficiently weighty reasons of justice to ensure that disputes are settled correctly beyond our borders.

111 European Union Committee on European Contract Law, n 22 above, Minutes of Evidence 9.

112 Tasioulas, $\mathrm{n} 49$ above, 103, relying on Raz (1986), n 67 above, 73-74.

113 Tasioulas, $\mathrm{n} 49$ above, 100.

114 Tasioulas, $\mathrm{n} 49$ above, 111. 


\section{(iii) Summary}

In summary, there is reason to doubt that the NJT is satisfied in this context on either economic or justice-related grounds. What needs to be shown is that Member States would better conform to these economic and justice-related reasons if they go along with the contract law harmonisation process, rather than seek to promote these objectives in some other way. However, it is far from clear that harmonisation of the general law of contract would promote cross-border trade between Member States; and, from the point of view of justice, only some states, ie, those that need to reform their pre-existing contract law regimes, would have reason to follow EU directives in this sphere. From the perspective of the NJT, the legitimacy of the DCFR appears both inconclusive and fragmentary.

\section{(c) Democracy}

Hershovitz distinguishes between 'substantive' and 'procedural' accounts of legitimacy. The NJT is a substantive theory, because it evaluates the content of directives, and determines whether they have beneficial effects for the putative subject. In contrast, a procedural theory focuses on how directives are enacted. He explains: 'Such a theory might judge, for example, whether the process was fair, deliberative, or public... We critique governments based on the degree to which people have access to the political process and equal efficacy within it. We often think, for example, that decision-making behind closed doors is inappropriate even if the decisions reached are good ones'. ${ }^{115}$

Thus, substantive and procedural theories might conflict in making legitimacy assessments. Substantive theories are outcome driven, whereas procedural theories focus on processes.

It is beyond the scope of this paper to settle which of these accounts offers the better account of legitimacy. ${ }^{116}$ Instead, I want to raise some doubts about whether the contract law harmonisation process might be legitimate on the basis of a procedural account of legitimacy.

A common view is that law-making processes are fair, deliberative, and so on, when they are democratic. At state level, democracy might require periodic elections, universal suffrage, and so on. In the context of international law-

115 Hershovitz, n 82 above, 212.

116 For a taste of the debate see Hershovitz, n 82 above; Raz (2006), n 67 above; J. Waldron, Law and Disagreement (Oxford: Clarendon Press, 1999). 
making institutions like the EU, it is unrealistic to expect this type of individualelectoral democracy. ${ }^{117}$ Instead, as Buchanan has argued the more feasible demand is for the instantiation of democratic values, such as the inclusive consideration of legitimate interests, through largely transparent deliberative processes'. ${ }^{118}$

The processes that have led to the development of the DCFR lack these democratic credentials. They have been largely technocratic. The DCFR is chiefly the product of collaboration between academic lawyers, rather than political actors. There have been participative elements, including public consultations and input from key stakeholders from the legal profession, consumer and business groups. However, as Miller has pointed out, there have also been 'alarming democratic gaps'. ${ }^{119}$ The Commission itself selected the stakeholders, and from those who were chosen business dominated. Consultancy firms played a central role in collating and presenting the responses from the public consultation exercises, which again skewed the process in favour of business interests. ${ }^{120}$ Stakeholders that were involved have complained. As Vogenauer reports: 'What I have heard from stakeholders is that they were generally rather frustrated by the process because they got the drafts at a very late stage and had very short meetings at which they had to discuss enormous amounts of provisions' ${ }^{121}$ National and European political institutions were also side-lined, leaving, Miller argues, 'a product bereft of political deliberation'. ${ }^{122}$

117 Buchanan, n 34 above, 87, 93.

118 Buchanan, n 34 above, 94. See also Study Group on Social Justice in European Private Law, n 26 above, 656-657, suggesting that in the context of the harmonisation of contract law, the democratic process should be suitably tailored to the context of multi-level governance. Cf Walker's distinction between 'integrated' and 'disaggregated' approaches to legitimacy in his 'The Philosophy of European Law', n 68 above, 12-15. The 'disaggregated' model represents the 'mass ballot-box' view of democracy, whereas the more realistic 'integrated' model focuses instead on: 'a multiplicity of finely grained engagements of knowledgeable and mutually responsive constituencies aimed at providing context-specific optimizations of the common good' (15). See more broadly J. Neyer, The Justification of Europe: A Political Theory of Supranational Integration (Oxford: Oxford University Press, 2012).

119 Miller, $\mathrm{n} 21$ above, 118.

120 Miller, $\mathrm{n} 21$ above, 118.

121 European Union Committee on European Contract Law, $\mathrm{n} 22$ above, Minutes of Evidence 17.

122 Miller, $\mathrm{n} 21$ above, 119. It is true that the DCFR is only the first step in a two-step process, which will involve the adoption by EU political institutions of a final or political Common Frame of Reference ('CFR'). However, the DCFR is likely to have a profound influence on the development of European private law. See N. Jansen and R. Zimmermann, 'A European Civil Code in All But Name' (2010) 69 Cambridge Law Journal 98; M.W. Hesselink, 'The Common Frame of Reference as 
It is no surprise that the Study Group on Social Justice in European Private Law reaches the verdict that this process has manifestly failed to 'provide a sufficiently inclusive dialogue for the examination and promulgation of fundamental principles of private law'. ${ }^{123}$ Instead, they say that what is needed is 'a broader scope for democratic participation, through the European Parliament, national legislatures, and perhaps national referenda'. ${ }^{124}$ More modestly, Vogenauer concludes that he 'would like to see another group, not only of academics but including Commission officials and - to use that phrase - stakeholders, giving them more time to come up with a draft that takes into account the criticism'. ${ }^{125}$

Whatever the remedy, it is clear that the processes adopted to come up with the DCFR fall markedly short of any plausible conception of democratic values that should apply in this context. This is particularly problematic in the context of the well-known democratic deficits that afflict EU institutions as a whole. ${ }^{126} \mathrm{Going}$ forward, the democratic legitimacy of the project will depend on the processes embracing a much greater degree of inclusivity and transparency.

\section{(d) Fairness}

Another broadly procedural theory of the conditions of legitimacy that seems relevant in this context is fairness. On this view, convergence may be legitimate because it is fair. The basic idea is that European citizens form a political community, and as such they have the right to equal treatment from European and national institutions when it comes to the creation and enforcement of contract law rights.

On this analysis, divergence of contract law raises an issue of fairness, because similarly situated people involved in contract disputes are treated differently depending on the jurisdiction in which their dispute arises. So, for example, we saw earlier that in England the innocent victim of a breach of contract has a

a Source of European Private Law' (2009) 83 Tulane Law Review 919, 923; Miller, n 21 above, $120-121$.

123 Study Group on Social Justice in European Private Law, n 26 above, 669.

124 Study Group on Social Justice in European Private Law, n 26 above, 669. See also M.W. Hesselink, 'The Politics of a European Civil Code' (2004) 10 European Law Journal 675.

125 European Union Committee on European Contract Law, n 22 above, Minutes of Evidence 16.

126 N. Fligstein, 'Who are the Europeans and How Does this Matter for Politics?', in J.T. Checkel and P.J. Katzenstein (eds), European Identity (Cambridge: Cambridge University Press, 2009) 132, 149. 
duty to mitigate her loss caused by the breach, but that no such requirement exists in France. This has the consequence that the victim of a breach of contract in England will be treated differently, ie, is under a duty to mitigate, even though her case is similar in all relevant respects to a case decided in France, where no duty to mitigate is imposed. She might complain that this is unfair. It is unfair that she has to bear the burdens of this rule, when the victims of breach in France don't. ${ }^{127}$

There is an obvious objection. Usually, complaints of unfairness arise when a single agent or institution is responsible for the differential treatment. However, in the mitigation example, it is not the same agent or institution responsible. Waldron makes an analogy (in the human rights context) that makes the point clear:

It is like a child who complains that her friends are allowed to stay up late on Sundays whereas she has to go to bed at 7:30: 'It's not fair!' she says. And we respond that no one is being unfair; other parents' practices are not binding here; that's not how we do things in this house. We don't determine the bedtime of your friend, so we are not being unfair to you when we send you to bed at a different time. ${ }^{128}$

Similarly, in the mitigation example, the English courts don't decide French contract law, and the French courts don't decide English contract law, therefore litigants in either jurisdiction can't complain that they are being treated unfairly vis-à-vis litigants in the other jurisdiction. No single authority is responsible for the differential treatment.

It could be argued that in the EU context national courts are now European courts, because they enforce European law, thus creating a single agency. However, the legislative competence of the EU is circumscribed by treaty, and does not extend to the general law of contract. ${ }^{129}$ Therefore, litigants cannot complain that a single agent is enforcing, for example, differential mitigation requirements.

However, Waldron has argued that the absence of a single agent is not fatal to a claim that differential treatment is unfair. He uses the following example to explain why:

127 Waldron, $\mathrm{n} 35$ above, 124-125.

128 Waldron, $n 35$ above, 126.

129 Although a fairness-based claim could be made in spheres where the EU clearly does have competence such as consumer law. This is an example of the derivative role that consent plays in determining questions of legitimacy. See text to notes $82-83$ above. 
Imagine a large refugee camp after a famine or humanitarian emergency, where, as often happens, several aid agencies and NGOs are working side by side with the same large population in the same camp. Suppose one of the organizations becomes aware that the provision it is offering the refugees is quite different in quantity and quality from the provision that the other aid agencies are offering to members of the same population in the same camp. Oxfam, for example, is giving two meals a day to the people in the north part of the camp, and other agencies are giving one meal a day to people in the southern sector, even though the people in the north are no more needy and no more deserving than those in the south... The people in the south are likely to be distressed by the disparate treatment. They are likely to complain that their treatment is unfair... And that demand does not presuppose a single agency responsible for all the treatment, although - and this is important - the complaint about unfairness may become the basis for a demand that the various agencies should start to behave as a unit. In other words, the demand for fairness could be a reason for the various entities to begin working as a system; their working as a system is not a precondition for the legitimacy of the demand..$^{130}$

The basis for the complaint of unfairness in the example, Waldron argues, is that there exists a community of people who are sufficiently related to one another to make these complaints seem reasonable. ${ }^{131}$ Waldron uses this analogy to argue for greater consistency in human rights law between jurisdictions. This is because there is now a transnational community of people, which is committed: 'specifically to advancing the idea of human rights for all, to pressuring governments (from whom we all have a lot to fear in this regard as well as a lot to hope for) to take rights seriously, and to watching out for each other when it comes to rights'. ${ }^{132}$

The existence of this interconnectedness of peoples when it comes to human rights issues, and the awareness by members of this community that human rights are not given the same level of protection across jurisdictions, leads to the demand, based on a principle of fairness, that governments converge when it comes to protecting human rights. ${ }^{133}$ To clarify, the sociological aspects of Waldron's argument here, ie, the actual existence of a relevant community of people, form an empirical premise in what is a philosophical or normative claim.

The question arises: does a transnational community exist in Europe that might justify a claim of equal treatment when it comes to the creation and enforcement of contract law rights? The formation of collective identity depends on whether a group 'accepts a fundamental and consequential sameness that causes them to feel solidarity amongst themselves'. ${ }^{134}$ In the European context,

130 Waldron, n 35 above, 131-132.

131 Waldron, $\mathrm{n} 35$ above, 132.

132 Waldron, $\mathrm{n} 35$ above, 133.

133 Waldron, $\mathrm{n} 35$ above, 133.

134 Fligstein, n 126 above, 134. 
what is required is akin to a sense of national identity. ${ }^{135}$ National identifications rely on the acceptance by disparate social groups of a shared narrative, usually combining a variety of elements, including history, religion, myth, ethnicity, and so on, 'into a potent vision of human identity and community'. ${ }^{136}$

Such a narrative may well be available for Europe. Emerging as it did in 1951 from the ashes of world war, Weiler argues that the heart of the European community is a fundamental commitment to celebrate the virtues of the liberal nation state, while keeping its excesses in check, 'especially, but not only, its propensity to violent conflict.... ${ }^{137}$ In an important sense, the European project is a 'post-national' enterprise. ${ }^{138}$ Priority is attached to the individual above the nation state, the upholding of human rights, non-discrimination on the basis of nationality, social solidarity, sustainable development and tolerance. ${ }^{139}$ According to Weiler, the idea of Europe represents 'the ability of the individual to rise above his or her national closet'. ${ }^{140}$

As I have said, it goes beyond my purpose in this article to evaluate this type of post-national conception of what the EU is for. However, whatever its merits might be, it can be said, with some confidence - particularly in the current political climate - that this vision has not been embraced. Rather, it has been imposed by elites in pursuit of admittedly laudable political and economic ends, including the creation of an internal market, the prevention of war and providing a counter-weight to the East and West. ${ }^{141}$ It lacks the 'bottom-up' impetus that is

135 Historically it is interesting to note that movements towards the convergence of private law have followed hot on the heels of the development of a sense of national identity. See Zimmermann, $\mathrm{n} 65$ above, 374, 390.

136 A.D. Smith, 'National Identity and the Idea of European Unity' (1992) 68 International Affairs 55, 61. Fligstein, n 126 above, 135-136, relying on Deutsch, n 59 above.

137 Weiler, $\mathrm{n} 58$ above, 341.

138 Smith, $\mathrm{n} 136$ above, 67.

139 Weiler, n 58 above, 344-345. Collins, n 93 above, 89-90. Hesselink, n 18 above, 359-360, arguing that in the contractual context looking out for the interests of the other party is a key component of European identity. See also Kennedy, n 23 above, 19-20, arguing that currently solidarity with weaker parties is a key theme of European private law; O. Lando, 'The Structure and the Legal Values of the Common Frame of Reference (CFR)' (2007) 3 European Review of Contract Law 245, 251.

140 Weiler, n 58 above, 343. For a longer-term picture of this sense of European identity see A. Pagden, 'Europe: Conceptualizing a Continent', in A. Pagden (ed), The Idea of Europe: From Antiquity to the European Union (Cambridge: Cambridge University Press, 2002) 33, and Anderson, n 73 above, ch 9 .

141 The achievement of these ends through the creation of economic and political institutions was the central plank of the Pan-European project. See Smith, n 136 above, 67. 
essential to the creation of a collective consciousness. ${ }^{142}$ As Neil Fligstein has shown, $87.3 \%$ of people in Europe conceive of themselves mostly in terms of their national rather than European identity. ${ }^{143}$ People are divided on class-based lines: 'People who tend to think of themselves as European represent the more privileged members of society, while people who tend to think of themselves as mainly national in identity tend to be less privileged'. ${ }^{144}$ As Anthony Smith says Europe's failure 'only underlines the distance between the European ideal and its rootedness in the popular consciousness of Europe's national populations'. ${ }^{145}$

Against this background, it is difficult to see how Waldron's empirical premise, the existence of an actual community of people, can be said to exist, with the result that the argument from fairness will struggle to get off the ground. This is not to say that a European identity will not emerge, but the political reality in the foreseeable future at least is, as Fligstein argues, that our national self-understandings will 'continue to trump' our European ones. ${ }^{146}$

\section{e) Summary}

I have raised some initial doubts in this section about the legitimacy of the EU contract law harmonisation effort, given plausible conceptions of the requirements of legitimacy in this context. There has been an over emphasis on the issue of consent, but consent is not a fundamental condition for legitimacy. The Commission still has some way to go to show that the NJT is satisfied, because it has not proven that convergence would promote the interests that states have in furthering cross-border trade. The argument that convergence would promote justice is more convincing, but does not go far enough. It does not show that there is a reason for convergence that is common to all states. Appealing to democratic arguments is problematic too, because the process by which the DCFR was developed was largely technocratic, and inadequately participative. Finally, the argument from fairness looks weak, given that there is an insufficiently robust sense of European identity embraced by the people of Europe, which is needed to justify such a claim.

142 Smith, n 136 above, 72-73.

143 Fligstein, n 126 above, 140.

144 Fligstein, n 126 above, 137.

145 Smith, $n 136$ above, 73.

146 Fligstein, n 126 above, 158. 


\section{The merits of convergence}

In the previous section, I raised some doubts about the legitimacy of the EU project to harmonise the general law of contract. The Commission needs to do more to show that the enterprise is legitimate. This is the fundamental problem that the emergence of a contract law for Europe faces. It is sometimes lost sight of in the literature.

As I said earlier, analytically it is important to distinguish the issue of legitimacy from the issue of the merits of convergence. Establishing that an authority has the right to rule does not necessarily mean that they should exercise that power. We have to weigh up the costs and benefits that ruling might have.

Even if the problem of legitimacy could be overcome, say by the use of more democratic processes or because of the emergence of a collective consciousness in Europe, ${ }^{147}$ we would still have to evaluate on the merits whether convergence would be desirable or indeed possible. This includes taking into account considerations of justice and fairness within states. It is beyond the scope of this paper to discuss these issues here. However, I will say something about a different concern, efficacy, which links to my claims about pluralism.

By efficacy, I mean the difficulty of ensuring consistent interpretation of the DCFR across 28 separate jurisdictions. There is an extensive literature on this issue, which has highlighted a number of potential obstacles. There is the problem of ensuring accurate translation of the DCFR text that is in English into the 23 official languages of the EU. ${ }^{148}$ Then there is the fact that the DCFR uses 'an astonishing number of vague and ambiguous terms....'. ${ }^{149}$ Another source of confusion is that the DCFR contains some badly drafted provisions. ${ }^{150}$

These issues to do with translation, vague terms and poor drafting make consistent interpretation an uphill task. I want to focus though on another related concern that links with the arguments I have made about interpretive and value pluralism.

147 Fligstein speculates on how a particular event, such as a terrorist atrocity affecting multiple EU states, might in the future bring about a sense of togetherness. Fligstein, n 126 above, 158-159.

148 Sefton-Green, n 19 above, 294, 290.

149 Stefan Vogenauer's evidence to European Union Committee on European Contract Law, n 22 above, Minutes of Evidence 14; Sefton-Green, n 19 above, 298.

150 See for example art II-4:105, which prevents reliance on 'No-Oral-Modification' ('NOM') clauses. For criticism of the provision see F. Wagner-von Papp, 'European Contract Law: Are No Oral Modification Clauses Not Worth the Paper They Are Written On?' (2010) 63 Current Legal Problems 511, 581. 
In an important article, Pierre Legrand made the following point: 'a code leads the jurist astray by suggesting that to have knowledge of the law is to have knowledge of the rules (and that to have knowledge of the rules is to have knowledge of the law!). Assuredly, ... jus is not reducible to lex ${ }^{{ }^{151}}$ Legrand relies here on Derrida's broader theory of interpretation, and in particular on a distinction Derrida drew between the 'graphical' surface level of a text and what he called its unseen 'trace' element, which 'indicate the presence of other discourses of which they are vestiges.... ${ }^{152}$

Legrand's thought is that rules even when they are clearly formulated are subject to interpretation, which is an evaluative exercise: ${ }^{153}$ 'Since they are invisible, the traces await their unfolding or elucidation or unconcealment - their bringing forth - by the text's interpreter.... ${ }^{154}$ Where there are multiple legal systems involved, interpretations will vary depending on the values that those systems embrace: 'What point, then, a unitary text of reference in the absence of a unitary rationality and morality to underwrite and effectuate it?'. There is no Archimedean or value neutral vantage point from which to determine the content of law. ${ }^{155}$

Take as an example the mitigation doctrine which I discussed earlier, and which is embraced by the DCFR (Article III-3:705). I argued that that doctrine might be justified on the basis of a number of values, including loss avoidance, fairness and altruism. Different jurisdictions will attach different weight to these values. This will influence how they interpret the requirements of the doctrine, and that will lead to divergences in application. ${ }^{156}$

Which values are embraced by a particular state may depend on local conditions. Gunther Teubner has argued that the reception of the good faith doctrine (introduced by the European Directive on Unfair Terms in Consumer Contracts

151 Legrand, n 59 above, 59-60.

152 P. Legrand, 'Siting Foreign Law: How Derrida Can Help' (2010) 21 Duke Journal of Comparative \& International Law 595, 607; P. Legrand, 'Paradoxically, Derrida: For a Comparative Legal Studies' (2005) 27 Cardozo Law Review 631, 674; J. Derrida, 'Living On', in H. Bloom, P. de Man, J. Derrida, G. Hartman and J.H. Miller (eds), De-construction \& Criticism (London: Routledge \& Kegan Paul, 1979) 62.

153 Legrand (2010), n 152 above, 609.

154 Legrand (2010), n 152 above, 609.

155 Legrand, n 59 above, 60. See also Legrand (2010), n 152 above, 601, 607-608, 611; Legrand (2005), n 152 above, 674-676. Legrand presents this theory of interpretation as a critique of legal positivism. See similarly Ronald Dworkin's argument from theoretical disagreement in his Law's Empire, $\mathrm{n} 35$ above, ch 1 .

156 Cf Tasioulas, The Legitimacy of International Law, n 49 above, 111, discussing the multiple ways of grounding the human right not to be tortured. 
1994), ${ }^{157}$ has been heavily influenced by the type of capitalism that particular Member States embrace. Countries like Germany have a 'business-coordinated market economy', where business plays a dominant role in shaping the economic framework and which is 'characterised by long-term cooperative relations between companies in the market, between companies and their employees, between companies and their owners and the suppliers of financial capital'. Against that backdrop, good faith has an important role to play in balancing 'the risks and opportunities which the mixture of autonomy and trust' create in this regime. ${ }^{158}$

In contrast, the British have a 'liberal market economy', where economic action is largely left to the market and relations between economic actors are characteristically adversarial. This is not a culture in which good faith can flourish. ${ }^{159}$ Instead, Teubner says, the doctrine has become a 'legal irritant'. These irritants may bring about change in the legal system, but it is likely that the evolutionary development that they catalyse will lead to divergence between legal systems.

My point here is just to illustrate how due to interpretive and value pluralism rules may be interpreted differently depending on which values a particular society embraces, and local conditions. This makes the prospects for integration around a common contract law in Europe hazardous. Reinhard Zimmermann reminds us that in past centuries the national codification movements in, for example, France and Germany, were supported by strong supreme courts, which ensured consistent interpretation of civil codes. In contrast, Zimmermann, commenting before the withdrawal of the proposed CESL, ${ }^{160}$ argued that were it enacted the European Court of Justice could not in its present form at least 'cope with the flood of requests for preliminary rulings that would result'. ${ }^{161}$

157 Council Directive 93/13/EEC of 5 April 1993 on Unfair Terms in Consumer Contracts [1993] OJEC L95/29.

158 G. Teubner, 'Legal Irritants: Good Faith in British Law or How Unifying Law Ends Up in New Divergences' (1998) 61 Modern Law Review 11, 25.

159 Teubner, n 158 above, 26-27. Cf Gómez, n 89 above, 103.

160 On the withdrawal of CESL see text to notes 13-15, above.

161 Zimmermann, n 65 above, 395. Making similar points about the weaknesses of the current system of judicial administration for the purposes of harmonising contract doctrine see: Walker, n 68 above, 23-24; Wagner, n 89 above, 1022: 'a uniform European law of contract is in urgent need of a European system of judicial administration in civil matters that is capable of resolving the many issues of doubt with which any civil code will invariably be afflicted'; E. Posner, 'The Questionable Basis of the Common European Sales Law: The Role of an Optional Instrument in Jurisdictional Competition' (2013) 50 (1/2) Common Market Law Review 261, 271 (relying on experience from the divergent ways in which different states have interpreted the UCC in the US); Gómez, n 89 above, 102, 105-106. 
Therefore, efficacy constraints of this nature have to be taken on board in taking any decision about whether a right to rule, even if established in this area, should be exercised.

\section{Conclusion}

The European Commission's 2001 consultation paper has set in train a process which has as its end the greater convergence of the general law of contract in Europe. It has led to the creation of the DCFR, which clearly has radical ambitions. As Vogenauer says:

The DCFR, as published in 2007, is much more than a 'toolbox' for a revision of the acquis, and it even goes beyond a potential European Contract Law Instrument. It is clearly meant to be a blueprint of a European Civil Code in the area of patrimonial law. ${ }^{162}$

Politically there is no appetite for a Civil Code, and it is not altogether clear what form harmonisation initiatives will take in the future. ${ }^{163}$ Against this background, I have attempted to use philosophical tools to unpack some of the main obstacles that harmonisation will face, whatever form it eventually takes.

I have made three claims. First, the central problem faced by harmonisation is legitimacy. It arises, because of the existence of interpretive and value pluralism and the value of state sovereignty, which gives states the right to decide the shape of their contract law. By exercising that right, states shape a valuable sense of national identity.

Second, there has been too much focus in the literature on the issue of consent as a condition of legitimacy. Consent is not an essential condition for the legitimacy of international law. Instead, we need to consider more plausible conditions that are relevant in this context, ie, the NJT, democracy and fairness. In light of these conceptions, I have expressed some doubts about the legitimacy of the harmonisation process. To satisfy the NJT, the Commission needs to provide better evidence of the economic benefits of harmonisation, and from the perspective of democracy, greater efforts have to be taken to ensure the inclusivity and transparency of decision-making in this field.

Finally, I have claimed that the issue of legitimacy, though central, does not exhaust the normative considerations that are in play. Even if the EU could

162 Evidence to European Union Committee on European Contract Law, n 22 above, Minutes of Evidence 3, para 14.

163 Wagner-von Papp, n 150 above, 512-513. 
establish the legitimacy of contract law harmonisation, there are reasons of efficacy linked to the existence of value and interpretive pluralism and the role that national courts play in adjudicating disputes in the EU that render harmonisation difficult. To reduce interpretive divergence between jurisdictions, the Commission needs to look at institutional reform, in particular strengthening the supervisory jurisdiction of the European Court of Justice. ${ }^{164}$

I do not deny that some of these issues are going to be more or less problematic depending on the form that harmonisation takes in the future. So, for example, Hesselink rightly points out that the use of an Optional Instrument that gives contracting parties the right to use European sales law is less of a threat to national identities than a Civil Code that would replace national contract law regimes. ${ }^{165}$ Nevertheless, the harmonisation enterprise generally and these initiatives specifically, all face, at least to some degree, questions about pluralism, sovereignty, legitimacy, efficacy, and so forth. Clarifying why these issues arise, the values they implicate, how they might be resolved, and so forth, will lead hopefully to a better quality of debate about harmonisation, and a better sense of the direction that the newly emergent contract law for Europe should take.

Acknowledgment: Earlier versions of this paper were presented at the 'Not Just Law III' conference at the University of Warwick (2014), and at the 'Obligations VII' conference at the University of Hong Kong (2014). Thank you to the conference participants on these occasions for extremely useful feedback. I would like to thank in particular for their advice Aditi Bagchi, Hugh Beale, Piet Eeckhout, Octavio Ferraz, Dora Kostakopoulou, George Letsas, Lucinda Miller, Dan Priel, Solène Rowan, Joanne Scott, John Tasioulas, Florian Wagner-von Papp and Simon Whittaker. Thank you also to the two anonymous referees from this journal for their feedback. Thank you finally to Simon Palmer for providing research assistance. The usual caveat applies.

164 Cf Posner, n 161 above, 271.

165 Hesselink, n 18 above, 365. 